\title{
Kajian Perlindungan E-Payment Berbasis Qr-Code dalam E-Commerce
}

\author{
Evelyn Angelita Pinondang Manurung ${ }^{1}$, Eka Ayu Purnama Lestari ${ }^{2}$ \\ ${ }^{12}$ Program Studi Teknik Informatika, STMIK STIKOM Indonesia, Indonesia
}

\begin{tabular}{|c|c|}
\hline & ABSTRACT \\
\hline $\begin{array}{l}\text { Keywords: } \\
\text { E-commerce; } \\
\text { Qr-code; } \\
\text { Electronic Payment System }\end{array}$ & $\begin{array}{l}\text { Abstrak: Recently, digital industry has developed rapidly and has given much } \\
\text { impact to the development of global industry in Indonesia. There are many } \\
\text { parties that get involved in it. The benefit of internet is mostly in every human } \\
\text { activity segment. One of social business activities that has developed rapidly is } \\
\text { online business, or mostly known as Electronic Commerce. In order to support } \\
\text { e-commerce activities, it needs an internet based payment system (internet } \\
\text { payment system). Nowadays, that has developed in some Marketplace that } \\
\text { already used the method called QR-Code (Quick Response Code) as its payment } \\
\text { method. This method has proved for its efficiency in the effectiveness of e- } \\
\text { commerce transaction. However, there is also polemic in the society about QR- } \\
\text { Code method. In order to do the payment using QR-Code method, people must } \\
\text { know about the technology and understand its implementation and functions. } \\
\text { Nowadays, people are being complacent by the ease offer by e-commerce } \\
\text { company by using QR-Code payment method without having sufficient } \\
\text { understanding and its security/law protection about QR-Code method. By } \\
\text { having a research regarding protection on electronic payment system QR-Code } \\
\text { based, it is expected that the costumers of e-commerce Indonesian people in } \\
\text { general understand have better understanding on how the implementation of } \\
\text { its payment and security methods in order to give protection to e-commerce } \\
\text { costumers. }\end{array}$ \\
\hline $\begin{array}{l}\text { Kata Kunci: } \\
\text { E-commerce; } \\
\text { Qr-code; } \\
\text { Sistem Pembayaran } \\
\text { Elektronik }\end{array}$ & $\begin{array}{l}\text { Abstrak: Pesatnya perkembangan industri digital saat ini, memberikan } \\
\text { pengaruh besar pada kemajuan terhadap industri global di Indonesia. Tentu } \\
\text { banyak pihak yang terlibat dalam industri digital tersebut. Manfaat internet saat } \\
\text { ini dirasakan hampir di setiap segmen aktifitas manusia. Salah satu aktifitas } \\
\text { bisnis masyarakat yang berkembang saat ini adalah perdagangan online, atau } \\
\text { populer disebut dengan Electronic Commerce. Untuk mendukung aktifitas } e \text { - } \\
\text { commerce diperlukan adanya suatu sistem pembayaran berbasis internet } \\
\text { (internet payment system). Saat ini yang berkembang di beberapa Marketplace, } \\
\text { telah menggunakan metode/sistem } Q R \text {-Code (Quick Response Code) sebagai } \\
\text { metode pembayarannya. Metode tersebut terbukti efisien dalam efektifitas } \\
\text { transaksi e-commerce. Namun, muncul juga polemik dalam masyarakat } \\
\text { mengenai metode } Q R \text {-Code. Untuk melakukan pembayaran dengan metode } Q R- \\
\text { Code, masyarakat harus melek teknologi dan mengerti tentang penerapan dan } \\
\text { fungsinya. Saat ini, masyarakat terlena dengan kemudahan yang ditawarkan } \\
\text { perusahaan } e \text {-commerce dengan metode pembayaran } Q R \text {-Code tanpa mengerti } \\
\text { dan memahami keamanan/perlindungan hukum tentang metode } Q R \text {-Code yang } \\
\text { jelas. Dengan adanya suatu kajian tentang perlindungan terhadap sistem } \\
\text { pembayaran elektronik berbasis } Q R \text {-Code diharapkan konsumen } e \text {-commerce } \\
\text { dan masyarakat Indonesia pada umumnya mengerti bagaimana penerapan } \\
\text { metode pembayaran tersebut dan keamanan metode pembayaran tersebut } \\
\text { dalam memberi perlindungan bagi konsumen } e \text {-commerce. }\end{array}$ \\
\hline
\end{tabular}

Correspondance address:

E-mail: ayulestari@stiki-indonesia.ac.id (Eka Ayu Purnama Lestari) 


\section{Pendahuluan}

Gencarnya perkembangan industri digital saat ini berdampak pada perubahan-perubahan yang membawa sebuah kemajuan terhadap industri global di Indonesia. Proses tersebut tentu saja mencakup banyak pihak yang terlibat dalam industri digital. Peran serta internet saat ini telah memasuki berbagai segmen aktifitas manusia terutama bidang ekonomi dan bisnis. Internet sangat dirasakan manfaatnya sebagai media aktifitas bisnis karena kontribusinya terhadap efisiensi. Aktifitas perdagangan melalui media internet populer disebut dengan Electronic Commerce. E-Commerce sendiri merupakan salah satu bentuk transaksi perdagangan yang paling banyak dipengaruhi oleh perkembangan teknologi informasi. Dimana sebagai wujud transaksi perdagangan barang atau jasa dengan menggunakan media elektronik. Jadi tidak heran adagium yang berkembang saat ini menyebutkan "e-commerce is a part of e-business".

Dahulu orang perlu datang ke kantor bank atau Anjungan Tunai Mandiri (ATM) untuk melakukan transaksi perbankan. Kini semuanya berubah karena transaksi dapat dengan mudah dilakukan melalui smartphone yang terhubung dengan jaringan internet (Buletin Investasi Kalimantan Timur, 2019). Perkembangan ilmu pengetahuan dan teknologi modern ini akan mengimplikasikan berbagai perubahan dalam kinerja manusia. Di era global saat ini, bertransaksi e-commerce melalui internet memang menawarkan kemudahan. Namun, memanfaatkan internet sebagai media aktivitas bisnis memerlukan perencanaan agar berbagai implikasi yang muncul dapat dikenali dan diatasi. Teknologi internet mempunyai pengaruh yang besar terhadap perekonomian dunia. Internet membawa perekonomian dunia memasuki segmen baru yang lebih popular dengan istilah digital economics atau prekonomian digital.

Untuk mendukung e-commerce, diperlukan adanya suatu sistem pembayaran berbasis internet (internet payment system) yang mengubah sistem pembayaran tradisional atau manual menjadi sistem pembayaran online. Melihat trend yang berkembang saat ini, beberapa Marketplace mulai menggunakan sistem $Q R$-Code sebagai metode pembayarannya. Sistem tersebut mengubah kebiasaan masyarakat banyak dari yang semula melakukan pembayaran cash menjadi cashless. Namun, tidak semua orang mengetahui dan paham mengenai sistem pembayaran cashless. Untuk melakukan pembayaran elektronik / cashless masyarakat harus melek teknologi. Penerapan sistem pembayaran elektronik berbasis $Q R$-Code memang dinilai efisien dalam berbagai aspek. Tetapi metode $Q R$-Code sendiri yang dikembangkan oleh perusahaan e-commerce di Indonesia perlu memiliki payung hukum yang jelas agar konsumen merasa aman dan tenang dalam melakukan pembayaran online. Dari penjelasan di atas maka saya akan mengupas lebih dalam penelitian ini bagaimana sesungguhnya penerapan dan keamanan sistem QR-Code (Quick Response Code) sebagai sistem pembayaran elektronik dalam e-commerce.

Terhadap suatu istilah sangat diperlukan agar dapat secara jelas memberikan suatu batasan ataupun lingkup pengertian yang tepat mengenai hal yang dibahas. Pratama (2015) menjelaskan bahwa e-commerce merupakan bentuk perubahan pola interaksi antara penjual dan pembeli dari kontak fisik dan tatap muka langsung menjadi berbasiskan internet dan pemasaran global yang lebih meluas. Wong (2010) menjelaskan bahwa e-commerce adalah pembelian, penjualan dan pemasaran barang serta jasa melalui sistem elektronik. Seperti radio, televisi dan jaringan komputer atau internet. Laudon (2014) Social networks have become a new e-commerce platform rivaling traditional ecommerce platforms by providing search, advertising, and payment services to vendors and customers. Dalam UU No.7/2014 tentang sistem elektronik dijelaskan bahwa sistem elektronik adalah perdagangan yang transaksinya dilakukan melalui serangkaian perangkat dan prosedur elektronik. Definisi-definisi tersebut memberikan pemahaman yang sama tentang apa itu e-commerce dan dapat dilihat bagaimana maraknya penggunaannya kini di masyarakat. Melihat trend e-commerce belakangan ini di berbagai wilayah dengan berbagai masalah yang ada, maka penulis tertarik mengetahui bagaimanakah perlindungan e-payment berbasis $Q R$-Code dalam transaksi e-commerce. 


\section{Metode}

Untuk memperlancar penelitian diperlukan data yang akurat, dalam penulisan ini memerlukan data-data yang ada hubungannya dengan judul. Maka dipakai metode yang mendukung, yakni metode kualitatif. Menurut Moleong (2005), penelitian kualitatif adalah penelitian yang bermaksud untuk memahami fenomena tentang apa yang dialami oleh subjek penelitian misalnya perilaku, persepsi, motivasi, tindakan, dll secara holistic, dan dengan cara deskripsi dalam bentuk kata-kata dan bahasa, pada suatu konteks khusus yang alamiah dan dengan memanfaatkan berbagai metode alamiah. Saryono (2010), penelitian kualitatif merupakan penelitian yang digunakan untuk menyelidiki, menemukan, menggambarkan, dan menjelaskan kualitas atau keistimewaan dari pengaruh sosial yanxg tidak dapat dijelaskan, diukur atau digambarkan melalui pendekatan kuantitatif.

Pendekatan terhadap permasalahan pada penelitian ini dilihat dari kepentingan analisis maupun pembahasannya adalah melalui pendekatan yuridis normatif yaitu mengkaji aturan/hukum tertulis dari berbagai aspek, yaitu meliputi aspek teori, sejarah, filosofi, perbandingan, struktur dan komposisi, lingkup dan materi, konsistensi, penjelasan umum, formalitas dan kekuatan mengikat serta undang-undang, bahasa hukum yang digunakan, tetapi tidak mengkaji aspek terapan atau implementasinya.

Tempat penelitian yang peneliti pilih adalah di Kota Denpasar. Tempat ini peneliti pilih karena merupakan domisili peneliti dan Kota Denpasar juga merupakan kota dengan kebiasaan penggunaan sistem pembayaran digital yang cukup tinggi. Pengumpulan data dilakukan dengan teknik studi pustaka atau studi dokumen (walaupun dilaksanakan juga pengumpulan data dengan penyebaran angket untuk melihat opini masyarakat) yang meliputi sumber primer, yaitu perundang-undangan yang relevan dengan permasalahan, sumber sekunder, yaitu buku-buku litreratur ilmu hukum serta tulisan-tulisan hukum lainnya yang relevan dengan permasalahan. Studi pustaka dilakukan melalui tahap-tahap identifikasi pustaka sumber data, identifikasi bahan hukum yang diperlukan dan inventarisasi bahan hukum yang diperlukan tersebut (Muhammad, 2004). Bahan-bahan atau data yang diperoleh baik bahan hukum primer maupun bahan hukum sekunder diolah dan dianalisis secara deskriptif kualitatif sesuai dengan permasalahan yang dibahas.

\section{Hasil dan Pembahasan}

\section{QR-Code Dalam Pembayaran Elektronik}

Kode Quick Responce atau yang disebut $Q R$ Code adalah keterangan mengenai barang yang berbentuk kode matrik yang memuat informasi mengenai nomor Sertifikat dan Identitas Pelanggan yang tercantum dalam Sertifikat (Peraturan Menteri Komunikasi dan Informatika Nomor 16 Tahun 2018).

Berikut ini beberapa istilah QR Code dintaranya sebagai berikut.

1. Quick Response Code untuk Pembayaran yang selanjutnya disebut $Q R$ Code Pembayaran adalah kode dua dimensi yang terdiri atas penanda tiga pola persegi pada sudut kiri bawah, sudut kiri atas, dan sudut kanan atas, memiliki modul hitam berupa persegi titik atau piksel, dan memiliki kemampuan menyimpan data alfanumerik, karakter, dan simbol, yang digunakan untuk memfasilitasi transaksi pembayaran nirsentuh melalui pemindaian (Peraturan Anggota Dewan Gubernur Nomor 21/18/PADG/2019 Tentang Implementasi Standar Nasional Quick Response Code Untuk Pembayaran Pasal 1 angka 4).

2. The $Q R$ Code is a two-dimensional version of the barcode, known from product packaging in the supermarket. Originally developed for process optimization in the logistics of the automotive industry, the QR Code has found its way into mobile marketing with the widespread adoption of smartphones. "QR" stands for "Quick Response", which refers to the instant access to the information hidden in the Code (https://www.qr-code-generator.com).

3. $Q R$ code is a contactless payment method where a payment is performed by scanning a $Q R$ code from a mobile app. A barcode is a machine-readable optical label that contains information about 
the item to which it is attached. In practice, $Q R$ codes often contain data for a locator, identifier, or tracker that points to a website or application (https://en.wikipedia.org/wiki/QR_code).

Di Indonesia, saat ini, tidak sedikit mucul perusahaan yang menyediakan jasa keuangan digital, seperti Gojek Indonesia yang memiliki fitur QR Code yang dikenal dengan GoPay; Telkomsel yang memiliki fitur pembayaran QR Code yang dikenal dengan TCash; dan OVO yang belakangan banyak diminati. Aplikasi uang elektronik atau sering disebut dompet digital yang menggunakan sistem QR Code juga saat ini tengah diminati masyarakat Indonesia salah satunya DANA yang diluncurkan oleh perusahaan Emtek dan Alipay.

Di Indonesia, juga tercatat beberapa bank umum terbesar telah merilis fitur $Q R$ Code sebagai inovasi terbaru di bidang teknologi finansial. Diantaranya sebagai berikut.

1. Bank Mandiri merilis Mandiri Pay.

2. BCA merilis aplikasi QRku.

3. BNI merilis aplikasi Yap!

4. BRI merilis aplikasi My QR.

Sebagian besar, metode e-payment dengan $Q R$ Code bisa digunakan untuk pengeluaran harian dengan nominal kecil, seperti makan, perlengkapan pribadi, pakaian, tagihan listrik, telepon, pulsa, dan aktivitas atau kewajiban rutin lainnya.

Transaksi e-payment dengan fitur $Q R$ Code memang tengah diminati sebagian besar masyarakat perkotaan. Mereka sangat merasakan keuntungan dari aplikasi digital tersebut diantaranya cepat prosesnya, praktis, mudah digunakan, efisien, serta iming-iming diskon (potongan harga) yang ditawarkan perusahaan penyedia layanan pembayaran digital tersebut.

Memang metode pembayaran berbasis $Q R$ Code ini bisa dijadikan alternatif baru bagi transaksi masyarakat. Di sisi lain, ada kekhawatiran bahwa kemudahan transaksi dengan QR Code memiliki risiko. Sejatinya selalu ada risiko dibalik teknologi baru, termasuk transaksi pembayaran menggunakan QR Code. Mekanisme ini bisa saja dimanfaatkan oknum tidak bertanggung jawab dengan cara mengirimkan $Q R$ Code palsu via aplikasi pesan singkat. Potensi penyalahgunaan data akan rentan terjadi, jika perusahaan penyedia layanan pembayaran dengan $Q R$ Code yang memiliki data pribadi konsumen/pelanggan membagikan data begitu saja kepada pihak ketiga. Dari hal tersebut menunjukkan kemajuan teknologi informasi perlu didukung oleh suatu peraturan yang dapat menjadi payung hukum.

Banyaknya perusahaan penyedia layanan pembayaran digital saat ini memacu pemerintah untuk mengeluarkan standar resmi transaksi $Q R$ Code. Pemerintah melalui Bank Indonesia regulator sistem pembayaran. Kehadiran perusahaan dan layanan QR Code tersebut juga sudah mulai banyak dimanfaatkan oleh masyarakat. Sangat diperlukan standardisasi QR Code untuk menerapkan sistem pembayaran yang saling terhubung.

\section{Regulasi E-Payment}

Sistem pembayaran elektronik telah berkembang pesat sejalan dengan inovasi teknologi yang disertai dengan kebiasaan masyarakat modern menggunakan layanan pembayaran digital melalui pemanfaatan berbagai teknologi termasuk $Q R$ Code. Digitalisasi dalam e-payment perlu dikembangkan dengan tujuan integrasi ekonomi dan keuangan digital nasional untuk penguatan dan kemajuan perekonomian nasional.

Pemanfaatan teknologi memerlukan langkah preventif terhadap adanya potensi penyalahgunaan dan dampak negatif dari perkembangan teknologi. Regulasi informasi dan transaksi elektronik melalui Undang-Undang Informasi Dan Transaksi Elektronik (UU ITE) Nomor 11 Tahun 2008 merupakan bentuk regulasi siber pertama di Indonesia. Regulasi tersebut menjadi dasar hukum penyelenggaraan sistem transaksi elektronik. E-Payment sebagai transaksi elektronik didefinisikan melalui UU ITE diantaranya sebagai berikut.

1. Pasal 1 angka 2. Transaksi Elektronik adalah perbuatan hukum yang dilakukan dengan komputer, jaringan komputer dan/atau media elektronik lainnya. 
2. Pasal 1 angka 5. Sistem Elektronik adalah serangkaian perangkat dan prosedur elektronik yang berfungsi mempersiapkan, mengumpulkan, mengolah, menganalisis, menyimpan, menampilkan, mengumumkan, mengirimkan, dan/atau menyebarkan Informasi Elektronik.

3. Pasal 1 angka 6. Penyelenggaraan Sistem Elektronik adalah pemanfaatan Sistem Elektronik oleh penyelenggara negara, Orang, Badan Usaha, dan/atau masyarakat.

4. Pasal 1 angka 15. Akses adalah kegiatan melakukan interaksi dengan Sistem Elektronik yang berdiri sendiri atau dalam jaringan.

5. Pasal 1 angka 16. Kode Akses adalah angka, huruf, simbol, karakter lainnya atau kombinasi di antaranya, yang merupakan kunci untuk dapat mengakses Komputer dan/atau Sistem Elektronik lainnya.

6. Pasal 4. Pemanfaatan Teknologi Informasi dan Transaksi Elektronik dilaksanakan dengan tujuan untuk:

a. mencerdaskan kehidupan bangsa sebagai bagian dari masyarakat informasi dunia;

b. mengembangkan perdagangan dan perekonomian nasional dalam rangka meningkatkan kesejahteraan masyarakat;

c. meningkatkan efektivitas dan efisiensi pelayanan publik;

d. membuka kesempatan seluas-luasnya kepada setiap Orang untuk memajukan pemikiran dan kemampuan di bidang penggunaan dan pemanfaatan Teknologi Informasi seoptimal mungkin dan bertanggung jawab; dan

e. memberikan rasa aman, keadilan, dan kepastian hukum bagi pengguna dan penyelenggara Teknologi Informasi.

Dari pasal di atas, menerangkan UU ITE mengatur penyelanggaraan transaksi elektronik termasuk metode e-payment, walaupun tidak menyebutkan penggunaan metode $Q R$ Code, namun dalam UU ITE mencakup aturan penggunaan kode akses dalam transaksi elektronik. Dalam Pasal 4 huruf e UU ITE juga memberikan perlindungan bagi pengguna dan penyelenggara teknologi informasi. Regulasi lainnya yang menjelaskan pemanfaatan e-payment adalah Peraturan Pemerintah Nomor 82 Tahun 2012 tentang Penyelenggaraan Sistem dan Transaksi Elektronik. Dalam Pasal 1, Peraturan Pemerintah tersebut menjelaskan hal-hal terkait transaksi elektronik, yaitu sebagai berikut.

1. Angka 1. Sistem Elektronik adalah serangkaian perangkat dan prosedur elektronik yang berfungsi mempersiapkan, mengumpulkan, mengolah, menganalisis, menyimpan, menampilkan, mengumumkan, mengirimkan, dan/atau menyebarkan Informasi Elektronik.

2. Angka 2. Transaksi Elektronik adalah perbuatan hukum yang dilakukan dengan menggunakan Komputer, jaringan Komputer, dan/atau media elektronik lainnya.

3. Angka 4. Penyelenggara Sistem Elektronik adalah setiap Orang, penyelenggara negara, Badan Usaha, dan masyarakat yang menyediakan, mengelola, dan/atau mengoperasikan Sistem Elektronik secara sendiri-sendiri maupun bersamasama kepada Pengguna Sistem Elektronik untuk keperluan dirinya dan/atau keperluan pihak lain.

4. Angka 6. Informasi Elektronik adalah satu atau sekumpulan data elektronik, termasuk tetapi tidak terbatas pada tulisan, suara, gambar, peta, rancangan, foto, electronic data interchange (EDI), surat elektronik (electronic mail), telegram, teleks, telecopy atau sejenisnya, huruf, tanda, angka, kode akses, simbol, atau perforasi yang telah diolah yang memiliki arti atau dapat dipahami oleh orang yang mampu memahaminya.

5. Angka 8. Teknologi Informasi adalah suatu teknik untuk mengumpulkan, menyiapkan, menyimpan, memproses, mengumumkan, menganalisis, dan/atau menyebarkan informasi.

6. Angka 9. Pengguna Sistem Elektronik adalah setiap Orang, penyelenggara negara, Badan Usaha, dan masyarakat yang memanfaatkan barang, jasa, fasilitas, atau informasi yang disediakan oleh Penyelenggara Sistem Elektronik.

Dalam Pasal 13, Penyelenggara Sistem Elektronik wajib menerapkan manajemen risiko terhadap kerusakan atau kerugian yang ditimbulkan. Pasal 15 (angka 1) Penyelenggara Sistem Elektronik wajib:

1. menjaga rahasia, keutuhan, dan ketersediaan Data Pribadi yang dikelolanya; 
2. menjamin bahwa perolehan, penggunaan, dan pemanfaatan Data Pribadi berdasarkan persetujuan pemilik data pribadi, kecuali ditentukan lain oleh peraturan perundang-undangan; dan

3. menjamin penggunaan atau pengungkapan data dilakukan berdasarkan persetujuan dari pemilik Data Pribadi tersebut dan sesuai dengan tujuan yang disampaikan kepada pemilik Data Pribadi pada saat perolehan data.

Regulasi yang menyangkut pentingnya perlindungan data pribadi dalam transaksi elektronik juga tercantum dalam Peraturan Menteri Komunikasi Dan Informatika Republik Indonesia Nomor 20 Tahun 2016 Tentang Perlindungan Data Pribadi Dalam Sistem Elektronik. Pasal 1 Dalam Peraturan Menteri, yaitu sebagai berikut.

1. Angka 1. Data Pribadi adalah data perseorangan tertentu yang disimpan, dirawat, dan dijaga kebenaran serta dilindungi kerahasiaannya.

2. Angka 2. Data Perseorangan Tertentu adalah setiap keterangan yang benar dan nyata yang melekat dan dapat diidentifikasi, baik langsung maupun tidak langsung, pada masing-masing individu yang pemanfaatannya sesuai ketentuan peraturan perundang-undangan.

3. Angka 3. Pemilik Data Pribadi adalah individu yang padanya melekat Data Perseorangan Tertentu.

4. Angka 4. Persetujuan Pemilik Data Pribadi yang selanjutnya disebut Persetujuan adalah pernyataan secara tertulis baik secara manual dan/atau elektronik yang diberikan oleh Pemilik Data Pribadi setelah mendapat penjelasan secara lengkap mengenai tindakan perolehan, pengumpulan, pengolahan, penganalisisan, penyimpanan, penampilan, pengumuman, pengiriman, dan penyebarluasan serta kerahasiaan atau ketidakrahasiaan Data Pribadi.

5. Angka 5. Sistem Elektronik adalah serangkaian perangkat dan prosedur elektronik yang berfungsi mempersiapkan, mengumpulkan, mengolah, menganalisis, menyimpan, menampilkan, mengumumkan, mengirimkan, dan/atau menyebarkan informasi elektronik.

6. Angka 6. Penyelenggara Sistem Elektronik adalah setiap Orang, penyelenggara negara, Badan Usaha, dan masyarakat yang menyediakan, mengelola, dan/atau mengoperasikan Sistem Elektronik secara sendiri-sendiri maupun bersama-sama kepada Pengguna Sistem Elektronik untuk keperluan dirinya dan/atau keperluan pihak lain.

7. Angka 7. Pengguna Sistem Elektronik yang selanjutnya disebut Pengguna adalah setiap Orang, penyelenggara negara, Badan Usaha, dan masyarakat yang memanfaatkan barang, jasa, fasilitas, atau informasi yang disediakan oleh Penyelenggara Sistem Elektronik.

Dalam Pasal 2 tersebut menjelaskan pentingnya perlindungan data dalam transaksi elektronik diantaranya sebagai berikut.

1. Angka 1; Perlindungan Data Pribadi dalam Sistem Elektronik mencakup perlindungan terhadap perolehan, pengumpulan, pengolahan, penganalisisan, penyimpanan, penampilan, pengumuman, pengiriman, penyebarluasan, dan pemusnahan Data Pribadi.

2. Angka 3; Privasi sebagaimana dimaksud pada ayat (2) huruf a merupakan kebebasan Pemilik Data Pribadi untuk menyatakan rahasia atau tidak menyatakan rahasia Data Pribadinya, kecuali ditentukan lain sesuai dengan ketentuan peraturan perundang-undangan.

Dalam Pasal 3 juga menerangkan agar setiap penyelenggaraan sistem elektronik memperhatikan Perlindungan Data Pribadi dalam Sistem Elektronik dilakukan pada proses berikut.

1. perolehan dan pengumpulan,

2. pengolahan dan penganalisisan,

3. penyimpanan,

4. penampilan, pengumuman, pengiriman, penyebarluasan, dan/atau pembukaan akses, dan

5. pemusnahan.

Dalam Pasal 5 angka 1, "Setiap Penyelenggara Sistem Elektronik harus mempunyai aturan internal perlindungan Data Pribadi" untuk melaksanakan proses sebagaimana dimaksud dalam Pasal 3.

Regulasi lainnya yang menjelaskan metode $Q R$ Code adalah Peraturan Menteri Komunikasi Dan Informatika Nomor 16 Tahun 2018 tentang "Ketentuan Operasional Sertifikasi Alat Dan/Atau Perangkat Telekomunikasi" yang tertuang dalam Pasal 1 angka 11 menyebutkan Kode Quick Responce 
yang selanjutnya disebut $Q R$ Code adalah keterangan mengenai barang yang berbentuk kode matrik yang memuat informasi mengenai nomor Sertifikat dan Identitas Pelanggan yang tercantum dalam Sertifikat. Dalam pasal tersebut jelas menyatakan $Q R$ Code berisi data rahasia berupa identitas pelanggan.

Pesatnya perkembangan industri berbasis teknologi informasi membuat masyarakat sadar akan pentingnya menjaga kerahasiaan data pribadi miliknya dari berbagai ancaman penyalahgunaan data. Kekhawatiran mengenai pelanggaran privasi dan perlindungan data pribadi dalam kode akses digital menjadi acuan bagi pemerintah untuk memikirkan perlindungan dan keamanan data pribadi masyarakat Indonesia terutama data-data yang sudah masuk dalam kode digital berupa QR Code.

Dalam rangka memberikan perlindungan dan keamanan bagi penyelenggaraan kegiatan transaksi elektronik, sejalan dengan UU ITE, Bank Indonesia telah menerbitkan berbagai pengaturan (regulasi) terkait penggunaan teknologi informasi dalam melakukan e-payment. Agar penggunaan $Q R$ Code dalam perekonomian keuangan digital berjalan optimal, ditetapkan standar nasional $Q R$ Code untuk pembayaran yang diberi nama QR Code Indonesia Standard (QRIS). Keberadaan QRIS diharapkan dapat memastikan efisiensi dan meminimalisir fragmentasi dalam praktik penggunaan $Q R$ Code untuk pembayaran. Di bulan Mei tahun ini Bank Indonesia (BI) akhirnya menerbitkan suatu aturan standardisasi $Q R$ Code sebagai sistem pembayaran, yaitu $Q R$ Code Indonesia Standard (QRIS). (https://www.bi.go.id/en/ruang-media/info-terbaru/Pages/Bank-Indonesia-Terbitkan-Ketentuan-

Pelaksanaan-QRIS.aspX). Peluncuran standar tersebut dilakukan sebagai langkah awal transformasi digital di Sistem Pembayaran Indonesia dalam membantu percepatan pengembangan ekonomi dan keuangan digital. Sebelumnya, aturan ini sempat tertunda untuk terbit. Dengan adanya $Q R$ Code Indonesia Standard (QRIS), memungkinkan pembayaran QR akan terkoneksi dengan menggunakan satu standar $Q R$ Code.

Disusul pada bulan Agustus tahun 2019 Bank Indonesia (BI) telah mengeluarkan peraturan tentang pedoman implementasi Quick Response (QR) Code Indonesian Standard (QRIS). Pedoman itu tertuang dalam Peraturan Anggota Dewan Gubernur (PADG) No.21/18/PADG/2019 tentang Implementasi Standar Nasional Quick Response Code untuk Pembayaran. QRIS merupakan standarisasi pembayaran QR Code. Dengan regulasi itu, pembeli/konsumen dapat melakukan pembayaran ke merchant melalui bank atau Penyelenggara Jasa Sistem Pembayaran (PJSP) apapun yang sudah terdaftar di QRIS Bank Indonesia (BI). Penerbitan regulasi tersebut bertujuan untuk memastikan penyelenggaraan layanan pembayaran yang menggunakan QRIS di Indonesia dapat berjalan dengan baik. Dengan adanya aturan ini, diharapkan tidak ada lagi monopoli atau eksklusivitas layanan platform pembayaran di merchant tertentu.

Penetapan QRIS juga prinsipnya sejalan dengan tatanan kebijakan Gerbang Pembayaran Nasional (GPN) yang ditujukan untuk mewujudkan penyelenggaraan sistem pembayaran yang aman, efisien, lancar, dan andal, mengutamakan perluasan akses dan memperhatikan perlindungan konsumen, serta mampu memproses seluruh transaksi pembayaran digital. Kewajiban penggunaan QRIS dalam setiap transaksi pembayaran berlaku juga bagi transaksi pembayaran di Indonesia yang difasilitasi QR Code Pembayaran dengan menggunakan sumber dana dan/atau instrumen pembayaran yang diterbitkan di luar wilayah Negara Kesatuan Republik Indonesia.

Dalam menjalankan kewenangannya Bank Indonesia mengacu pada empat prinsip kebijakan sistem pembayaran, yakni keamanan, efisiensi, kesetaraan akses, dan perlindungan konsumen. Aman berarti segala risiko dalam sistem pembayaran seperti risiko likuiditas, risiko kredit, risiko fraud harus dapat dikelola dan dimitigasi dengan baik oleh setiap penyelenggaraan sistem pembayaran. Prinsip efisiensi menekankan bahwa penyelanggaran sistem pembayaran harus dapat digunakan secara luas sehingga biaya yang ditanggung masyarakat akan lebih murah karena meningkatnya skala ekonomi. Kemudian prinsip kesetaraan akses yang mengandung arti bahwa BI tidak menginginkan adanya praktek monopoli pada penyelenggaraan suatu sistem yang dapat menghambat pemain lain untuk masuk. Kemudian kewajiban seluruh penyelenggara sistem pembayaran untuk memperhatikan aspekaspek perlindungan konsumen (https://www.bi.go.id/id/sistem-pembayaran/Contents/Default.aspx). Teknologi jika penggunaan dan pemanfaatannya dengan cara yang baik dapat membantu aspek kehidupan manusia, namun sebaliknya teknologi juga dapat menjadi ancaman apabila tidak dibatasi 
penggunaannya, seperti dalam hal tidak dilindunginya data pribadi karena tidak terdapat kewajiban dalam hukum positif yang secara rinci mengatur dan memberikan sanksi terhadap pelanggaran. Bahaya tersebut dapat timbul dari adanya pencurian data pribadi yang ada dalam QR Code, kerusakan sistem yang dapat memungkinkan terjadinya pembobolan data termasuk data pribadi, penyalahgunaan data pribadi yang telah dikuasai oleh pelaku usaha itu sendiri ataupun pihak-pihak lainnya yang dapat mengakses data pribadi konsumen.

Disamping segala manfaat dan potensi QR Code payment kedepannya, masyarakat harus aware dengan risiko yang mungkin muncul khususnya dari fraudster. Salah satu ancaman yang berpotensi terjadi ialah "fake QR Code" atau QR Code palsu. Fraudster dapat mengganti barcode/kode bar tersebut dengan barcode yang tidak sah, sehingga dana yang ditransfer nasabah saat melakukan pembayaran akan masuk ke rekening bukan pemilik merchant. Lebih dari itu barcode tersebut juga dapat disusupi dengan virus, sehingga saat nasabah melakukan scan barcode tersebut secara tidak sadar ponsel mereka akan terinstall virus yang akan mencuri data-data konsumen tersebut dan dapat menyebabkan kerugian finansial. Selain itu keunikan barcode system tersebut tentunya akan menyulitkan nasabah dalam melakukan verifikasi keabsahan barcode tersebut.

\section{Simpulan}

Berdasarkan uraian di atas, maka pengaturan hukum berkaitan dengan penggunaan $e$ payment berbasis QR Code terdapat pada Undang-Undang Nomor 11 Tahun 2008 Tentang Informasi Dan Transaksi Elektronik, Peraturan Pemerintah Nomor 82 Tahun 2012 Tentang Penyelenggara Sistem Dan Transaksi Elektronik, Peraturan Menteri Komunikasi Dan Informatika Republik Indonesia Nomor 20 Tahun 2016 Tentang Perlindungan Data Pribadi Dalam Sistem Elektronik, Peraturan Menteri Komunikasi Dan Informatika Nomor 16 Tahun 2018 Tentang Operasional Sertifikasi Alat Dan/Atau Perangkat Telekomunikasi. Sejalan dengan UU ITE yang menjadi pionir pengaturan transaksi elektronik, Bank Indonesia telah menerbitkan regulasi terkait e-payment yaitu standar nasional QR Code untuk pembayaran yang diberi nama QR Code Indonesia Standard (QRIS), itu tertuang dalam Peraturan Anggota Dewan Gubernur (PADG) No.21/18/PADG/2019 tentang Implementasi Standar Nasional Quick Response Code untuk Pembayaran. Maka saat ini pengaturan mengenai e-payment berbasis QR Code sesungguhnya telah diakomodir oleh pemerintah sebagai penyelenggara negara, begitu juga dari semua regulasi tersebut telah diatur perlindungan hukum dalam sistem pembayaran elektronik dengan metode QR Code.

\section{Daftar Pustaka}

https://en.wikipedia.org/wiki/QR code, diakses 28 Mei 2019.

https://www.bi.go.id/en/ruang-media/info-terbaru/Pages/Bank-Indonesia-Terbitkan-KetentuanPelaksanaan-QRIS.aspx, diakses 10 Juni 2019.

https://www.bi.go.id/id/sistem-pembayaran/Contents/Default.aspx, diakses 25 September 2019.

Muhammad. 2004. Hukum dan Penelitian Hukum. Bandung: Citra Aditya Bakti.

Pratama. 2015. E-Commerce E-Business Dan Mobile Commerce. Bandung: Informatika.

Wong. J. 2010. Internet Marketing For Beginners. Elex Media Komputindo.

Laudon, K. C. \& Carol Guercio Traver. 2014. E-Commerce: Business Technology-Society. New York University.

Moleong. 2005. Metodologi Penelitian Kualitatif. Bandung: Remaja Rosdakarya. 
36 Jurnal Penelitian dan Pengembagan Sains dan Humaniora, Vol 4(1) April 2020, h. 28-36

Provinsi Kalimantan Timur. 2019. Pasar Pembayaran Digital Indonesia - Era Ekonomi Digital, Buletin Investasi Kalimantan Timur Edisi April-Juni 2019.

Saryono. 2010. Metode Penelitian Kualitatif Dalam Bidang Kesehatan. Yogyakarta: Nuha Medika.

Undang-Undang Nomor 11 Tahun 2008 Tentang Informasi Dan Transaksi Elektronik.

Peraturan Pemerintah Nomor 82 Tahun 2012 Tentang Penyelenggara Sistem Dan Transaksi Elektronik.

Undang-Undang Nomor 7 Tahun 2014 Tentang Perdagangan.Peraturan Menteri Komunikasi Dan Informatika Nomor 20 Tahun 2016 Tentang Perlindungan Data Pribadi.

Peraturan Menteri Komunikasi Dan Informatika Nomor 16 Tahun 2018 Tentang Ketentuan Operasional Sertifikasi Alat Dan/Atau Perangkat Telekomunikasi.

Peraturan Anggota Dewan Gubernur Nomor 21/18/PADG/2019 Tentang Implementasi Standar Nasional Quick Response Code Untuk Pembayaran. 